\title{
PENERAPAN LAYANAN UNGGUL DALAM PEMASARAN PRODUK BANK
}

\author{
Oleh : \\ Effendi Sinuhaji
}

\begin{abstract}
Abstrak
Penelitian ini bertujuan untuk merumuskan upaya yang efektif dalam peningkatan pelayanan kepada nasabah dengan memberikan layanan unggul, mengidentifikasi faktor-faktor pendorong dan penghambat yang mempengaruhi nasabah dalam melakukan transaksi, serta mengevaluasi kesiapan perusahaan dalam mengimplementasikan upaya-upaya yang telah ditetapkan. Metode yang digunakan adalah survey yang tujuannya memperoleh data dalam bentuk kualitatif, sedangkan pengumpulan datanya dilakukan melalui observasi, wawancara dan studi dokumen, yang digunakan untuk mencari data aktivitas sehari-hari penerapan layanan unggul dalam pemasaran produk bank. Analisis data dengan tiga langkah yaitu reduksi data, penyajian data dan penarikan kesimpulan/verifikasi sebagai prosedur untuk menghasilkan data deskriptif. Hasil penelitian menunjukkan bahwa penerapan layanan ungggul dari pihak Bank dalam menyelesaikan pengaduan/keluhan dari nasabah dapat meningkatkan pemasaran produk, dengan kata lain, penerapan pelayanan yang baik, cepat dan profesional akan dapat memberikan kepuasan, ketenangan dan kepercayaan bagi nasabah.
\end{abstract}

Keyword : Layanan Unggul, Pemasaran Produk.

\section{PENDAHULUAN}

Memperoleh keuntungan merupakan tujuan utama berdirinya suatu badan usaha, baik badan usaha yang berbentuk Perseroan Terbatas (PT), Yayasan maupun bentuk-bentuk badan usaha lainnya. Keuntungan yang diperoleh tidak saja digunakan untuk membiayai operasi perusahaan, seperti membayar gaji serta biaya-biaya lainnya, akan tetapi juga digunakan untuk ekspansi perusahaan melalui berbagai kegiatan dimasa yang akan datang.

Dalam praktiknya tidak semua badan usaha yang didirikan memperoleh keuntungan seperti yang diharapkan, bahkan tidak sedikit badan usaha yang mati sebelum berkembang, akibat terus-menerus menderita kerugian. Dampak kerugian yang diderita oleh suatu badan usaha bukan hanya membangkrutkan perusahaan akan tetapi juga mengakibatkan terjadinya Pemutusan Hubungan Kerja (PHK) terhadap karyawannya yang pada akhirnya akan berakibat menganggurnya karyawan perusahaan yang bersangkutan. Agar suatu badan usaha tidak menderita kerugian atau dengan kata lain harus memperoleh keuntungan seperti yang ditargetkan, maka badan usaha perusahaan tersebut perlu mengelolanya secara profesional. Tanpa pengelolaan yang profesional jangan diharapkan suatu perusahaan akan dapat memperoleh keuntungan seperti yang diharapkan.

Dalam usaha untuk memperoleh keuntungan tersebut maka perusahaan menjual produk dan/ataupun jasa kepada para konsumennya. Salah satu perusahaan yang 
menjual jasa adalah Bank. Bank merupakan perusahaan yang menyediakan jasa keuangan bagi seluruh lapisaan masyarakat. Fungsi bank merupakan perantara di antara masyarakat yang membutuhkan dana dengan masyarakat yang kelebihan dana, disamping menyediakan jasa-jasa keuangan lainnya. Oleh karena bank berfungsi sebagai perantara keuangan, maka dalam hal ini faktor "kepercayaan" dari masyarakat merupakan faktor utama dalam menjalankan bisnis perbankan.

Manajemen bank dihadapkan berbagai upaya untuk menjaga kepercayaan tersebut, sehingga dapat memperoleh simpati dari para calon nasabahnya. Untuk menjaga dan meningkatkan kepercayaan nasabahnya, maka bank perlu menjaga citra positif dimata nasabah. Untuk mendapatkan citra positif tersebut perbankan melakukan berbagai cara, diantaranya dengan kegiatan pemasaran. Dalam kegiatan pemasaran tersebut maka bank harus berinteraksi langsung dengan nasabah yang akan menyebabkan terjadinya pertemuan dua karakter dan keinginan yang saling berbeda. Perbedaan tersebut sering memunculkan persinggungan kepentingan yang jika tidak diantisipasi lebih jauh akan mengakibatkan suatu hubungan yang tidak baik antara bank dan nasabah yang tentunya akan mempengaruhi citra perbankan.

Untuk meningkatkan citra perbankan tersebut maka bank perlu menyiapkan personil yang mampu menangani keinginan dan kebutuhan nasabahnya. Personil tersebut memegang peranan penting disamping memberikan layanan juga membina hubungan dengan masyarakat atau nasabah yang juga diharapkan mampu untuk memenuhi kebutuhan dan keinginan nasabahnya. Namun dalam praktik kesehariannya, tidak jarang nasabah merasakan kebutuhan dan keinginannya tersebut tidak dapat dipenuhi oleh bank. Pada dasarnya nasabah berpendapat bahwa bank atau personil bank tersebut tidak dapat memenuhi kebutuhan dan keinginan mereka sesuai dengan apa yang mereka harapkan atau tidak sesuai dengan janji dan promosi yang didengungkan. Ada rasa ketidakpuasan atas layanan yang diberikan oleh bank atau personil bank tersebut. Bahkan dalam penyelesaian ketidakpuasan tersebut tidak jarang nasabah juga memperoleh rasa ketidakpuasan tambahan lainnya, seperti : lambatnya proses penyelesaian komplain, tidak tanggapnya personil bank terhadap keluhan nasabah, dan sebagainya.

Kesemua permasalahan tersebut pada dasarnya berasal dari ketidakpedulian serta ketidaktanggapan bank ataupun personil bank akan kebutuhan layanan yang diinginkan nasabah. Untuk memperoleh simpati dari nasabah maka pihak manajemen bank harus memberikan layanan yang terbaik. Layanan memiliki peran yang sangat strategis, sebab mampu meningkatkan jumlah nasabah. Namun sebaliknya layanan yang buruk dapat dengan mudah mengurangi jumlah nasabah. Berita buruk lebih cepat penyebarannya dibandingkan dengan berita baik. Oleh karena itu unsur layanan perlu mendapat perhatian yang serius dari perusahaan. Layanan tumbuh dan berkembang melalui proses evolusi dalam masyarakat, seiring dengan kemajuan teknologi dan informasi dewasa ini sehingga kadang memunculkan kebutuhan-kebutuhan yang semakin beragam. Bagi perusahaan-perusahaan yang bergerak dibidang jasa perbankan banyak cara yang dilakukan agar dapat menarik nasabah, hal ini tentu melalui produkproduk yang ditawarkan.

\section{TINJAUAN}

Kata "layanan unggul" atau "layanan prima" dalam dunia bisnis sekarang dinyatakan dengan istilah Service Excellent atau disingkat sebagai SEX. Adakah perbedaan antara 
layanan unggul dengan layanan reguler yang diberikan kepada nasabah umumnya. Sebetulnya tidak begitu jauh berbeda, bahkan dapat dikatakan sama, karena pada hakikatnya layanan unggul bertitik tolak pada upaya pelaku bisnis untuk memberikan layanan terbaiknya sebagai wujud kepedulian perusahaan kepada konsumen. Jikapun ada perbedaan, hanyalah sedikit saja, yaitu karena perbedaan dalam penggunaan berbagai konsep pendekatannya saja.

Menurut Barata (2003) pengertian layanan unggul adalah Kepedulian kepada pelanggan dengan memberikan layanan terbaik untuk memfasilitasi kemudahan pemenuhan kebutuhan dan mewujudkan kepuasan pelanggan, agar mereka selalu loyal kepada organisasi/perusahaan. Sedangkan menurut Boediono (2003) pelayanan pelanggan adalah Upaya yang secara sadar dan terencana dilakukan organisasi atau badan usaha agar produk/jasanya menang dalam persaingan melalui pemberian/penyajian pelayanan kepada pelanggan, sehingga tercapai kepuasan optimal bagi pelanggan.

Salah satu cara agar penjualan jasa satu perusahaan lebih unggul dibandingkan para pesaingnya adalah dengan memberikan pelayanan yang berkualitas dan bermutu, yang memenuhi tingkat kepentingan konsumen. Tingkat kepentingan konsumen terhadap jasa yang akan mereka terima dapat dibentuk berdasarkan pengalaman dan saran yang mereka peroleh. Konsumen memilih pemberi jasa berdasarkan peringkat kepentingan. Dan setelah menikmati jasa tersebut mereka cenderung akan membandingkannya dengan yang mereka harapkan. Bila jasa yang mereka nikmati ternyata berada jauh dibawah jasa yang mereka harapkan, para konsumen akan kehilangan minat terhadap pemberi jasa tersebut. Sebaliknya, jika jasa yang mereka nikmati memenuhi atau melebihi tingkat kepentingan, mereka akan cenderung memakai kembali produk jasa tersebut.

Menurut Kasmir (2004) standar layanan tersebut adalah (1) Tersedianya sarana dan prasarana yang baik. Nasabah ingin dilayani secara prima. Untuk melayani nasabah maka salah satu hal yang paling penting diperhatikan adalah sarana dan prasarana yang dimiliki. Meja dan kursi harus nyaman untuk diduduki. Udara dalam ruangan juga harus tenang, tidak berisik dan sejuk. Kelengkapan dan kenyamanan sarana dan prasarana ini akan mengakibatkan nasabah betah untuk berurusan dengan perusahaan, (2) Tersedianya personil yang baik. Kenyamanan nasabah juga sangat tergantung dari petugas yang melayaninya. Petugas harus ramah, sopan dan menarik. Disamping itu petugas juga harus cepat, tanggap serta pandai bicara untuk menyenangkan nasabah, sehingga nasabah semakin tertarik. Demikian juga cara kerja petugas juga harus cepat dan cekatan. Untuk ini semua, sebelum menduduki posisi pekerjaannya tersebut, petugas bersangkutan harus melalui pendidikan dan pelatihan khusus layanan, (3) Bertanggung jawab kepada setiap nasabah sejak awal transaksi hingga selesai. Dalam menjalankan kegiatan pelayanannya, petugas harus mampu melayani nasabah dari awal sampai tuntas atau selesai. Nasabah akan merasa puas jika petugas bertanggung jawab terhadap pelayanan yang diinginkannya. Jika terjadi sesuatu maka segera petugas yang dari semula mengerjakannya segera mengambil alih tangguh jawabnya, (4) Mampu melayani secara cepat dan tepat. Dalam melayani nasabah maka diharapkan petugas harus melakukan tugasnya sesuai prosedur yang ada. Layanan yang diberikan sesuai jadwal untuk pekerjaan tertentu dan jangan membuat kesalahan dalam arti pelayanan yang diberikan sesuai dengan keinginan nasabah, (5) Mampu berkomunikasi. Petugas harus mampu berkomunikasi dengan baik kepada setiap nasabah. Petugas harus mampu dengan cepat memahami keinginan nasabah. Artinya, petugas harus dapat 
berkomunikasi dengan bahasa yang jelas dan mudah dimengerti. Jangan menggunakan istilah yang sulit dimengerti nasabah, (6) Memberikan jaminan kerahasiaan setiap transaksi. Menjaga rahasia nasabah sama artinya dengan menjaga kelangsungan hidup pegawai. Pegawai digaji atas tugas layanannya kepada nasabah yang secara pribadi tidak ingin rahasianya diketahui orang lain. Jika petugas membuka rahasia nasabah, sama artinya petugas merusak kelangsungan hidupnya sendiri. Oleh karena itu petugas harus mampu menjaga rahasia nasabah terhadap siapapun. Rahasia bank merupakan taruhan kepercayaan nasabah kepada Bank, (7) Petugas memiliki pengetahuan dan kemampuan yang baik. Untuk melayani nasabah yang selalu ingin dipuasi kebutuhannya maka petugas juga harus melengkapi dirinya dengan pengetahuan dan kemampuan yang baik. Layanan yang baik hanya bisa diberikan oleh petugas yang memiliki pengetahuan dan kemampuan melayani yang baik. Untuk itu petugas harus dididik secara khusus mengenai kemampuan dan pengetahuan untuk menghadapi nasabah atau kemampuan dalam bekerja, (8) Berusaha memahami kebutuhan nasabah. Petugas harus cepat dan tanggap terhadap apa yang diinginkan oleh nasabah. Petugas yang lambasn akan membuat nasabah lari. Usahakan untuk selalu mengerti dan memahami keinginan dan kebutuhan nasabah, (9) Mampu memberikan kepercayaan kepada nasabah. Kepercayaan calon nasabah mutlak diperlukan perusahaan sehingga calon nasabah tersebut mau menjadi nasabah perusahaan. Dan tidak kalah pentingnya adalah upaya perusahaan untuk secara secara terus menerus dan berkesinambungan dalam menjaga nasabah yang lama agar tidak lari dari perusahaan.

Tingkat kualitas pelayanan tidak dapat dinilai berdasarkan sudut pandang perusahaan tetapi harus dipandang dari sudut pandang penilaian pelanggan. Karena itu, dalam merumuskan strategi dan program pelayanan, perusahaan harus berorientasi pada kepentingan pelanggan dengan memperhatikan komponen kualitas pelayanan. Menurut Berry, dkk (2000) ada lima kriteria pokok yang menentukan kualitas suatu pelayanan, yang dikenal dengan Dimensi Kualitas Pelayanan, yaitu (1) Reliability (Keandalan), yaitu kemampuan untuk melakukan pelayanan sesuai dengan yang dijanjikan dengan segera, akurat dan memuaskan. (2) Responsiveness (Ketanggapan), yaitu kemampuan untuk membantu pelanggan dan ketersediaan untuk melayani pelanggan dengan baik. (3) Assurance (Jaminan), mencakup pengetahuan, kemampuan, kesopanan, dan sifat dapat dipercaya yang dimiliki para staf, bebas dari bahaya, resiko atau keragu-raguan. (4) Empathy (Empati), meliputi kemudahan dalam melakukan hubungan, komunikasi yang baik, perhatian pribadi, dan memahami kebutuhan para pelanggan. (5) Tangibles (Bukti langsung), meliput fasilitas phisik, perlengkapan pegawai, dan sarana komunikasi.

Faktor-faktor yang mempengaruhi mutu pelayanan menurut Barata (2003) adalah :

1. Pembuatan Strategi, Dalam rangkaian proses penyajian pelayanan unggul, strategi ditempatkan pada urutan pertama, artinya menentukan manfaat (benefit) apa yang diberikan kepada konsumen. Setelah itu barulah ditentukan bentuk layanan yang dapat menghasilkan manfaat seperti yang diharapkan. Kualitas layanan berhubungan dengan tingkat pelayanan yang diberikan, sesuai dengan yang diharapkan target market. Strategi yang berhasil merupakan representasi dari kemampuan perusahaan yang sesuai dengan harapan konsumen. Maka proses pembuatan strategi sangat penting dalam mempengaruhi mutu pelayanan. Jika strategi yang diterapkan tidak tepat, maka layanan yang diberikan juga tidak akan memberikan kepuasan bagi nasabah. 
2, Kepemimpinan (Leadership), Melalui kepemimpinan ini, strategi dapat direalisasikan pada kegiatan sehari-hari. Semakin besar keterlibatan manajer tingkat atas pada pelayanan, maka perusahaan semakin mampu memberikan pelayanan yang baik pula. Seorang pemimpian yang langsung turun tangan melayani nasabah akan menjadi teladan yang baik bagi para karyawan. Dengan adanya teladan tersebut akan mempermudah karyawan dalam melaksanakan strategi yang telah ditentukan.

3. Sumber Daya Manusia, Perilaku karyawan menjadi faktor yang penting untuk diperhatikan. Masalahnya, yang menjalankan semua strategi yang dibuat adalah manusia. Sebagian besar pelayanan diberikan dalam bentuk tatap muka langsung antara pegawai dan konsumen. Jika pegawai tidak dapat menjalankan strategi yang telah ditetapkan maka pemberian layanan juga tidak akan memberikan hasil yang maksimal dalam memenuhi kebutuhan/keinginan nasabah.

4. Desain produk atau jasa, Produk dan jasa sebaiknya didesain untuk kemudahan atau kenyamanan konsumen atau nasabah. Diupayakan agar nasabah dapat menggunakan produk dan jasa tersebut dengan aman, mudah dan menguntungkan. Ketidakpuasan nasabah sering juga terjadi karena produk dan jasa yang ditawarkan tidak memberikan kemudahan, melainkan kesulitan dalam menggunakannya. Contoh : tabungan yang belum on-line sehingga menyulitkan nasabah untuk bertransaksi di luar cabang pembuka rekening. Untuk menghindari hal-hal seperti ini tentu diperlukan orang-orang yang berkompeten untuk terlibat dalam proses desain suatu produk atau jasa tersebut.

5. Infrastruktur, Infrastruktur ini adalah fakta pendukung dari pelayanan. Misalnya, untuk senantiasa meningkatkan kemampuan para karyawannya, maka perlu adanya departemen pelatihan. Ataupun perusahaan membuat data base informasi mengenai nasabah dan produk atau jasa. Membangun infrastruktur cukup memakan biaya karena tuntutan konsumen saat ini semakin beragam. Pada intinya mereka membutuhkan pelayanan yang cepat dan tepat. Untuk itu, diperlukan suatu back up berupa alat bantu yang umumnya berteknologi canggih. Namun secara jangka panjang, pembangunaan infrastruktur ini lebih murah dan memberikan dampak positif bagi perusahaan.

6. Pengukuran Pelayanan, Pengukuran ini menjadi feedbank bagi para pengambil keputusan untuk mengetahui keberhasilan strategi yang dijalankan.

Sedangkan pengertian pemasaran menurut Mc.Nair (2000) adalah Penyediaan barang dan jasa yang tepat kepada orang yang tepat pada waktu yang tepat, harga yang tepat dengan komunikasi dan promosi yang tepat. Menurut Kotler (2005 pemasaran adalah Suatu proses sosial dan melalui proses itu individu-individu dan kelompok memperoleh apa yang mereka butuhkan dan inginkan dengan cara menciptakan dan mempertukarkan produk dan jasa dengan individu dan kelompok lain. Menurut Larreche, dkk (2000) pemasaran adalah suatu proses sosial yang melibatkan kegiatan-kegiatan penting yang memungkinkan individu dan perusahaan mendapatkan apa yang mereka butuhkan dan inginkan melalui pertukaran dengan pihak lain dan untuk mengembangkan hubungan pertukaran.

Sedangkan pemasaran menurut Foster (2000) pemasaran adalah fungsi manajemen yang mengorganisasi dan menjuruskan semua kegiatan perusahaan yang meliputi penilaian dan pengubahan tenaga beli konsumen menjadi permintaan yang efektif terhadap sesuatu barang atau jasa serta penyampaian barang atau jasa tersebut kepada konsumen terakhir atau pemakai, sehingga perusahaan dapat mencapai laba atau tujuan lain yang ditetapkannya. Menurut Sudjoni (2000) pemasaran adalah proses sosial dimana individu 
dan kelompok mendapat apa yang mereka butuhkan dan inginkan dengan menciptakan dan mempertukarkan produk dan nilai dengan individu atau kelompok lainnya.

\section{METODE}

Dalam mendapatkan data dari penelitian ini digunakan metode survey yang tujuannya memperoleh data dalam bentuk kualitatif. Adapun pengumpulan datanya dilakukan melalui observasi, wawancara dan studi dokumen. Metode ini digunakan untuk mencari data aktivitas sehari-hari penerapan layanan unggul dalam pemasaran produk bank. Adapun analisis data dilakukan dengan tiga langkah yaitu reduksi data, penyajian data dan penarikan kesimpulan/verifikasi sebagai prosedur untuk menghasilkan data deskriptif berupa kata-kata tertulis atau lisan dari orang-orang serta perilaku yang dapat diamati (Bogdan dan Guba dalam Suharsaputra : 2009).

\section{PEMBAHASAN}

Fokus dari dinamika perbaikan kualitas perbankan terletak pada kepuasan nasabah (customer satisfaction), oleh karena itu perlu dipahami hal-hal yang berkaitan dengan nasabah. Nasabah adalah semua orang yang menuntut suatu bank untuk memenuhi suatu standard kualitas tertentu dan karena itu memberikan pengaruh pada performance perbankan. Salah satu upaya yang dilakukan adalah dengan menerapkan Standar Layanan Unggul bagi para nasabah sehubungan dengan hal tersebut, Divisi Layanan menetapkan standar layanan yang menjadi acuan kerja bagi seluruh unit kerja di Bank.

Standar layanan petugas Satuan Pengamanan (Satpam) antara lain (1) Senyum, sampaikan salam dan menjaga kontak mata, (2) Bahasa tubuh yang benar, (3) Memberikan rasa aman kepada nasabah, (4) Menawarkan bantuan atau memberi informasi, (5) Katakan terima kasih, ucapkan salam penutup (Divisi SDM : 2003).

Adapun standar layanan Customer Service adalah (a) Senyum, sampaikan salam, kontak mata dan tawarkan bantuan dengan antusias, (b)Inisiatif menggali kebutuhan nasabah, (c) Mampu menjelaskan fitur produk dan layanan kepada nasabah, (d) Proses permintaan nasabah dengan cepat, (d) Aktif melakukan verifikasi dan konfirmasi, (e) Tanggapi permintaan nasabah dengan empati dan berupaya mempertahankan nasabah yang berniat menutup rekening, (e) Ingat untuk selalu menawarkan produk/jasa/fasilitas lainnya, dan (f) Katakan terimakasih, ucapkan salam penutup (Divisi SDM : 2003).

Sedangkan standar layanan Teller, yakni (1) Antusias, senyum dan sampaikan salam, (2) Kontak mata dan tawarkan bantuan, (3) Ucapkan selalu nama nasabah, (4) Ramah dan cepat dalam melayani nasabah, (5) Aktif melakukan verifikasi dan konfirmasi, dan (6) Terimakasih dan sampaikan salam penutup.

\section{Layanan Unggul Dalam Meningkatkan Pemasaran Produk}

Dalam kaitannya dengan pelayanan kepada pelanggan, semua pihak yang bergerak dalam pemberian layanan yang bersifat komersil maupun non-komersil harus menyadari, bahwa keberadaan konsumen yang setia (loyal) merupakan pendukung untuk kesuksesan perusahaan. Dengan demikian mereka harus menempatkan konsumen sebagai aset yang sangat berharga, karena dalam kenyataannya tidak akan ada satupun perusahaan yang akan mampu bertahan hidup bila ditinggalkan oleh pelanggannya.

Satu-satunya jalan untuk mempertahankan kelanjutan perusahaan adalah dengan cara mengembangkan pola layanan terbaik, antara lain dengan cara (a) Memperhatikan 
perkembangan kebutuhan dan keinginan para pelanggan dari waktu ke waktu, untuk kemudahan mengantisipasinya, (b) Berupaya menyediakan kebutuhan pelanggan sesuai dengan keinginan atau lebih dari yang diharapkan, dan (c) Memperlakukan pelanggan dengan pola layanan terbaik. Dari waktu ke waktu, masyarakat berjuang untuk meningkatkan kualitas hidup dalam rangka mencapai kehidupan yang lebih sejahtera. Sejalan dengan itu, tentu saja kebutuhan dan keinginan masyarakat (konsumen/pelanggan) terus berubah semakin meningkat, sehingga strategi dalam melayani pelanggan harus terus dikembangkan ke arah yang lebih baik dari sebelumnya. Para penyedia layanan, terutama di bidang bisnis, sangat memahami bahwa pelanggan membutuhkan layanan yang baik, sehingga mereka tahu pasxti, bahwa memuaskan pelanggan adalah keharusan. Merekapun menyadari, jika mereka mampu memberikan layanan yang baik, secara langsung atau tidak langsung, kebaikan layanannya akan tersebar luas karena kepuasan yang dirasakan pelanggannya akan disampaikan oleh pelanggan yang satu ke pelanggan lainnya secara berantai. Promosi sinergis yang gratis, bukan ? Layanan yang baik merupakan daya tarik yang besar bagi para pelanggan, sehingga korporat bisnis seringkali menggunakannya sebagai alat promosi untuk menarik minat pelanggan. Jadi, dewasa ini, disamping menonjolkan kualitas produk (barang dan jasa) sebagai wujud layanan, para pelaku bisnis menonjolkan juga pola layanan lainnya sebagai penunjang untuk memberikan perhatian atau keakbraban kepada pelanggannya, yang kemudian dikenal sebagai kepedulian terhadap pelanggan (customer care).

Konsep kepedulian perusahaan untuk memberikan layanan kepda pelanggan didasarkan pada pemahaman mengenai pentingnya pernan pelanggan dalam kelangsungan hidup dan kemajuan perusahaan. Program pelayanan kepada nasabah dengan bertitik tolak dari konsep kepedulian kepada konsumen terus dikembangkan sedemikian rupa, sehingga sekarang ini program layanan telah menjadi salah satu alat utama dalam melaksanakan strategi pemasaran untuk memenangkan persaingan. Kepedulian kepada nasabah dalam manajemen modern telah dikembangkan menjadi suatu pola layanan terbaik yang disebut sebagai layanan unggul atau layanan prima.

Dengan adanya program layanan unggul yang mengembangkan konsep kepedulian kepada pelanggan maka diharapkan akan menimbulkan kepuasan bagi pelanggan, yang pada akhirnya juga akan menimbulkan kesetiaan pelanggan kepada perusahaan. Jika kesetiaan telah timbul maka akan mempermudah perusahaan untuk memasarkan produk lainnya kepada pelanggan. Jika konsep layanan unggul telah diterapkan dengan baik dan secara menyeluruh, maka akan meningkatkan kepercayaan pelanggan kepada perusahaan. Kepercayaan adalah faktor penting yang diinginkan pelanggan dari perusahaan. Jika pelanggan tidak mempercayai petugas ataupun perusahaan maka akan sulit bagi perusahaan untuk memasarkan produknya. Namun jika kepercayaan itu telah tumbuh kuat pada pelanggan, maka pelanggan percaya bahwa yang dipasarkan baginya adalah yang terbaik yang dapat diberikan perusahaan. Dengan demikian akan semakin mempermudah petugas atau perusahaan untuk memasarkan produknya, yang pada akhirnya akan meningkatkan pemasaran produk perusahaan.

\section{DAFTAR PUSTAKA}

Atep Adya Barata, Dasar-Dasar Pelayanan Prima, PT. Elex Media Komputindo, Jakarta, 2003.

B. Boediono, Pelayanan Prima Perpajakan, PT. Rineka Cipta-Jakarta, 2003. 
Divisi Sumber Daya Manusia, Selling Culture, PT. Bank Negara Indonesia (Persero) Tbk, Jakarta, 2003.

Divisi Sumber Daya Manusia, Service Excellence, PT. Bank Negara Indonesia (Persero) Tbk, Jakarta, 2003.

Douglas, W., Foster, Dasar-Dasar Marketing, Erlangga, Jakarta, 2000.

Harper W. Boyd, Jr., Orville C.Walker, Jr., Jean-Claude Larreche, Manajemen Pemasaran, Suatu Pendekatan Strategis Dengan Orientasi Global, Erlangga, Jakarta, 2000.

Irawan, Faried Wijaya M., Sudjoni, Manajemen Pemasaran, BPFE, Yogyakarta, Edisi Pertama, 2000.

Kasmir, Manajemen Perbankan, Edisi I, Cetakan Kelima, PT.raja Grafindo Persada, Jakarta, Desember 2004.

Kasmir, Pemasaran Bank, Penerbit Kencana, Jakarta, April 2004.

Malcom P. McNair, Marketing dan the Social Challenge of Our Times, Chicago, American Marketing Association, 2000.

Parasuraman, Zeithaml, Berry, Dimensi Kualitas Pelayanan, Erlangga, Jakarta, 2000.

Philip Kotler, Marketing Management, Prentice-Hall, Inc., 2005.

Uhar Suharsaputra, Metode Penelitian Kualitatif, http://uharsputra.files. wordpress.com/2007/05/kuliah-2-penel-kualitatif.doc, dikunjungi 19 Pebruari 2009. 